\title{
CRiminal LAW AND PUNISHMENT IN THE MIDDle AgeS IN SLOVAKIA
}

\author{
УГОЛОВНОЕ ПРАВО И НАКАЗАНИЕ \\ В СРЕДНИЕ ВЕКА В СЛОВАКИИ
}

\begin{abstract}
The paper describes the development of the system of punishment in our territory from the oldest times up to the modern times. It points out the fundamental difference from the current legal situation: while there is currently the most commonly imposed punishment, imprisonment, in the past there was a «diverse range» of punishment, with imprisonment (as we know it today) at the earliest time ever there. Even in later developmental stages, when it already existed, the motivation of its imposition was different from the present and its imposition was still a rare phenomenon.

\section{Аннотация}

В статье рассказывается о развитии системы наказаний на территории современной Словакии с древних времен до XV века. Это указывает на принципиальное отличие от нынешней правовой ситуации: в то время как приговоры к лишению свободы в настоящее время существуют как наиболее часто назначаемое наказание, в прошлом существовал "разнообразный диапазон» приговоров. Даже на более поздних стадиях развития, когда лишение свободы как наказание уже существовало, его мотивация была иной и оставалось редким явлением.
\end{abstract}


KEYWORDs: history of law, Slovak republic, middle ages, modern times, imprisonment, alternative punishments.

Ключевые слова: История права, Словачкая республика, Средневековье, современность, тюремное заключение, альтернативные наказания.

Характер уголовного права в Средние века и в первые века Нового времени на территории современной Словакии диаметрально отличался от характера современного уголовного права. В средние века не было слов «уголовное право», «уголовный процесс» или «преступление» (но для простоты мы будем использовать данные современные термины), a также не было отдельной юридической отрасли, посвященной исключительно наказанию за преступления. Не было и различия между законом государственного и частного секторов. Однако, если бы мы описали средневековое уголовное право, понимая разделение права на публичное и частное, в ранние времена его характер был бы почти исключительно частным. Наказание за преступление было единственной ответственностью жертвы (или его семьи), и государственные власти в основном не были вовлечены в эти отношения (постепенное вовлечение государственных органов в наказание начинается позже, в средние века).

На заре средневековья возбуждение уголовного процесса начиналось главным образом потерпевшей стороной (либо оставшимися в живых, либо их семьями), и без этой инициации наказание не состоялось. Аналогично, законодательство в ранние времена не было включено в письменные правовые нормы, но имело характер неписаных правовых обычаев (которые лишь постепенно дополнялись правилами церкви или правителей). Не было никакого установленного диапазона нарушений или никаких установленных последствий в форме штрафов. Целью наказания также не была защита общества или исправление правонарушителя, но целью наказания была простая месть. Характер доказательств в уголовном процессе основывался главным образом на средствах иррационального характера.

Даже после гибели Великой Моравии и присоединения территории современной Словакии к Венгрии характер уголовного права 
принципиально не отличался от характера Великой Моравии. Уголовное право по-прежнему носило преимущественно частный характер, и наказание за преступление в основном находилось в компетенции потерпевшей стороны или его семьи (а государственные органы изначально не были вовлечены в эти отношения). Что касается убийства, убитая семья могла «обеспечить справедливость» путем самопомощи и убить убийцу или другого члена его семьи. Применялось правило «зеркального наказания» (выраженное в Библии как «око за око, зуб за зуб»).С преступником поступали аналогично его действиям с жертвой. Также в законах Иштвана I Святого мы находим: «Поэтому, если кто-то изуродует либо чьи-то глаза, либо ногу или руку обнаженным мечом, пусть они будут наказаны с таким же повреждением их тела». Если у убитого не было выживших, способных на кровную месть, то его убийство могло остаться безнаказанным (Gábriš, 2016).

Однако в Венгрии возможность выкупа от наказания также относительно скоро вступила в законную силу. По законам Иштвана I Святого было сказано: «Если кто-то, раздраженный гневом или несущий гордость, совершает добровольное убийство, пусть он знает, что согласно решению нашего совета выплачивается сто десять золотых, пятьдесят из которых пойдут в королевскую казну, остальные пятьдесят - родителям и десять - судьям, а также посредникам. Согласно каноническим правилам, пусть ассасин сам постится. - Но если кто-то случайно кого-то убьет, он платит двенадцать золотых, и, поскольку он командует каноническим законом, пусть он постится. - Если один слуга убивает слугу другого (хозяина), пусть слуга будет считаться слугой или искупит сказанное и покается. Однако, если свободный человек убивает другого слугу, пусть он даст слугу, или пусть он договорится о вознаграждении и позволит ему поститься по каноническому закону» (Kolárik, 2010, p. 27-29). Однако не только за убийство, но и за преступление против здоровья можно было требовать компенсации. За имущественные преступления можно было так же требовать компенсацию за поврежденную вещь. Как и в Великой Моравии, в Венгрии это изменение в правопорядке было вызвано влиянием распространения христианства. 
Предполагается, что основной мотивацией для освобождения от наказания было (среди прочего) сохранение высоких затрат на месть. Таким образом, экономический эффект преобладал над удовлетворением мести: для раненых или оставшихся в живых примирение путем согласованной компенсации или «выкупа» было более выгодным, чем сама месть. (Adamová, 2006). Для заключенного также было выгодно заключить соглашение или выкуп: после его заключения с правонарушителем обращались так, как будто он не совершил никакого действия, и его честь была сохранена или восстановлена. Покаяние также использовалось в таких соглашениях. Второстепенной мотивацией также может быть то, что первоначально члены семьи, в отношении которых будет проводиться кровная месть, могут снова отомстить членам семьи, которая отомстила. После заключения договора или выплаты выкупа такого риска больше не было (Segeš, 2014, p. 108-122). ${ }^{1}$

Уголовный процесс в Венгрии принял форму так называемого процесса обвинения. Уголовный процесс начинался ся по частному ходатайству (например, потерпевшая сторона или семья убитого). Без такого частного предложения уголовное дело изначально не было возбуждено. Сам процесс проходил публично и, в принципе, устно. Истец и ответчик были сторонами в разбирательстве. Если стороны не примирились в ходе судебного разбирательства, началось само доказательство, в котором стороны спора представили доказательства.

Уголовныйпроцесс былслегкаизмененво времяправления венгерской династии Анжу: обвинение изначально дополнялось следственным принципом. Изменение состояло в том, что судья мог вмешаться без частного истца, и в то же время мог сам принимать доказательства. В отличие от предыдущего периода, документальные доказательства считались основным средством доказательства, особенно тех, которые были выданы заслуживающим доверия местом. Уголовный процесс постепенно стал возможным благодаря применению признания подсудимого с помощью пыток. И в этом случае иррациональное мнение заключалось в том, что если обвиняемый невиновен, пытки будут продолжаться. Сама пытка проходила в несколько этапов: сначала 
обвиняемому показывали инструменты пыток, если он не признавался, вводили более легкую форму пыток, если он не признавался, начинались более жестокие пытки. Согласно средневековым обычаям, пытки не должны были вызывать смерть обвиняемого или наносить серьезный ущерб здоровью (поэтому пытка могла продолжаться только определенное время, и между различными фазами должен быть временной интервал). В отличие от суровых испытаний, члены церкви больше не участвовали в пытках, но ее исполнение находилось в руках светской власти. Хотя в современную эпоху постепенно отказываются от признаний в форме пыток, его фактический запрет восходит к эпохе Просвещения. (Segě̌, 2015, p. 72-84 )

Что касается самого наказания, телесные и наносящие вред наказания чаще всего выполнялись в средние века. Телесные и калечащие приговоры постепенно «дополнялись» наказаниями, затрагивающими имущество правонарушителя и его семьи. Что касается наказаний, затрагивающих имущество преступника, необходимо отметить, что в древние времена в нашем понимании не было индивидуальной собственности. Таким образом, было возможно не только наказать имущество преступника: если преступник был наказан за имущество, это наказание автоматически затронуло и имущество его семьи. В то же время, преступник был не только наказан, но и его семья могла быть «наказана». Даже в период позднего средневековья мы неоднократно доказывали, что, например, за нападение на монарха или его близкого человека казнили не только самого преступника, но и членов его семьи. Вышеупомянутое коллективное наказание семьи правонарушителя было оправдано в современных условиях, среди прочего, превентивными действиями семьи в предотвращении преступления против личности, а также психологическим эффектом страха преступника, что, если он совершит преступление, его семья понесет последствия.

По сравнению со структурой и формой наказаний, наложенных в Новое время, примечательно, что первоначально в его более позднем понимании практически не было тюремного заключения. Хотя у нас есть много доказательств существования «подземелий», «темниц» или «голода» (для простоты, мы будем использовать только термин 
«темницы» ниже) из средневековья, они не служили в первую очередь для «отбывания наказания в виде лишения свободы» (Gábriš, 2019). Человек, который был помещен в темницу, был интернирован там главным образом, чтобы помешать ему убежать. В темнице человек «ждал» вердикта по своему делу. После «вынесения приговора» человек чаще всего подвергался физическому наказанию, отправлялся в изгнание, продавался в рабство (существовало в нашей стране до XII века) или был приговорен к подстрекательству, или человек был казнен. В Высоком или Позднем Средневековье применение «тюремного заключения» было редким явлением (данный термин отсутствовал в этот период истории).

\section{Bibliography}

\section{Использованная литература}

Adamová K. (2006). Světla a stíny středověkého práva, Praha: Havlíček Brain Team. ISBN 9788090360945.

Ferenčíková S., Michalov L. (2018). Penologické aspekty. W: S. Romža (red.) Alternatívne spôsoby výkonu trestov, Košice: Univerzita Pavla Jozefa Šafárika v Košiciach, s. 129-137.

Ferenčíková S., Tóthová V. (2018). Kriminologické aspekty. W: S. Romža (red.) Alternatívne spôsoby výkonu trestov, Košice: Univerzita Pavla Jozefa Šafárika v Košiciach, s. 115-128.

Ferenčíková S., Tóthová V. (2019). Innovation In Criminal Policy Of Imposing Alternative Sanctionsin Slovak Justice. International Conference On Innovations In Science And Education, Prague.

Gábriš T., Jáger R. (2016). Najstaršie právo na Slovensku? Pokus o rekonštrukciu predcyrilometodského normatívneho systému, Bratislava: Wolters Kluwer. ISBN 9788081685071.

Gábriš T. (2019). Back to Slavic Legal History? On the Use of Historical Linguistics in the History of Slavic Law. Frühmittelalterliche Studien. Volume 53 (1). ISSN 00719706.

Klimek L. (2017). Základy trestného práva Európskej únie, Bratislava: Wolters Kluwer. ISBN 9788081686016.

Klimek L. (2017a). Mutual Recognition of Judicial Decisions in European Criminal Law. Cham, DEU: Springer. ISBN 9783319443775. 
Kolárik J. (2010). Právne dejiny Slovenska, Bratislava: Eurokódex, 2010, s. 27-29. ISBN 9788089447282.

Madar M. (2012). Trest smrti - komparácia vybraných historických a právnych súvislostí. Notitiae Novae Facultatis Iuridicae Universitatis Matthiae Beli Neosolii. Banská Bystrica: Právnická fakulta Univerzita Mateja Bela.

Madar M. (2019). Judikatúra vo veciach sankcií v trestnom práve, Bratislava: Wolters Kluwer. ISBN 9788081689956.

Mosný P. (2015). Dejiny štátu a práva na území Slovenska I. od najstarších čias po rok 1848, Bratislava: Wolters Kluwer. ISBN 9788081683268.

Saturník T. (1922). Příspěvky k šírení byzantského práva u Slovanů, Prague: Nákladem české akademie věd a umění.

Segeš V. (2004). Žena ako subjekt a objekt kriminality v stredovekej Bratislave, Žena a právo. Právne a spoločenské postavenie žien v minulosti, Bratislava, s. 57-65.

Segeš V. (2005). Prešporský pitaval - zločin a trest v stredovekej Bratislave, Bratislava: Perfekt. ISBN 8080463115.

Segeš V. (2006). Justícia v stredovekom Prešporku. Kapitoly $z$ dejín Bratislavy, Bratislava: Kaligram, s. 100-125.

Segeš V. (2006). Zločiny podl’a Tripartita. Historická revue, 5, s. 23-25. ISSN 13356550.

Segeš V. (2014). Sexuálne trestné činy a ich postih v stredovekej Bratislave v kontexte uhorského práva. Sexuální trestní činy včera a dnes. Ostrava: The European Society for History of Law - KEY Publishing, s. 108-122.

Segeš V. (2015). Postih trestných činov proti životu a zdraviu v stredovekej Bratislave. Trestné činy proti životu a zdraví včera a dnes, Ostrava: The European Society for History of Law - KEY Publishing, s. 72-84.

Turošík M. (2010). Právne následky krádeže v rímskom práve. Delicta privata a crimina publica v rímskom práve, Košice: Univerzita Pavla Jozefa Šafárika, Právnická fakulta, s. 24-31.

Turošíková A., Turošík M. (2016). Komparatívny pohlad na inštitút krádeže v rímskom civilnom a slovenskom trestnom práve. Civilnoprávne inštitúty a ich historická reflexia vo svetle moderných kodifikácí, Banská Bystrica: Belianum, s. 83-92.

Статья представляет собой результат грантового проекта APVV-16-0362 «Приватизация уголовного права - материально-правовые, процедурные, криминологические и организационно-технические аспекты». 


\section{Endnotes}

${ }^{1)}$ Adamová K.: Světla a stíny středověkého práva. Praha: Havlíček Brain Team, 2006, s. 100. Porovnaj s Segeš V.: Prešporský pitaval - zločin a trest v stredovekej Bratislave. Bratislava: Perfekt, 2005, s. 111-119. Segeš V.: Postih trestných činov proti životu a zdraviu v stredovekej Bratislave. In: Tauchen, Jaromír - Schelle, Karel a kol.: Trestné činy proti životu a zdraví včera a dnes. Ostrava: The European Society for History of Law - KEY Publishing, 2015, kap. I/7, s. 72-84; Segeš V.: Sexuálne trestné činy a ich postih v stredovekej Bratislave v kontexte uhorského práva. In: Schelle, Karel - Tauchen, Jaromír a kol.: Sexuální trestní činy včera a dnes. Ostrava: The European Society for History of Law - KEY Publishing, 2014, s. 108-122; Segeš V.: Justícia v stredovekom Prešporku. In: Kapitoly z dejín Bratislavy. Bratislava: Kaligram, 2006, s. 100-125; Segeš V.: Fenomén vojny a mieru v stredoveku. In: Vojenská história, 7, 2003, č. 3, s. 3-11; Segeš V.: Zločiny podla Tripartita. In: Historická revue, roč. 5, 1994, s. 23-25; Segeš V.: Žena ako subjekt a objekt kriminality v stredovekej Bratislave. In: Žena a právo. Právne a spoločenské postavenie žien v minulosti. Ed. T. Lengyelová. Bratislava 2004, s. 57-65. 